\title{
Not Drowning, Waving: Images, History, and the Representation of Asylum Seekers
}

\section{Desmond Manderson}

Since Jeremy Bentham 200 years ago, the concept of law in the developed world has been dominated by a thoroughgoing consequentialism. The purpose of the law, according to Bentham and all those who follow in his footsteps, can be summed up in a single word: utility. Law is thought of not as a symbolic or normative structure so much as a system that causes changes in behaviour by instilling pain or pleasure. This consequentialist logic is based on the assumption that we know, by and large, what effects flow from what causes and can therefore accurately calibrate the consequences on behaviour of any particular legal change. Our actions are intentional and their consequences are predictable. Of course, this is precisely the arrogance behind such a philosophy. Migration law provides a rich tapestry to demonstrate the ways in which our legal intentions and actions bear many, and often gravely counter-productive, fruit. The pages of this volume are devoted to demonstrating the futility, paradox, or irony of a more complex relationship between intention and consequence. 


\section{If you come here by boat without a visa}
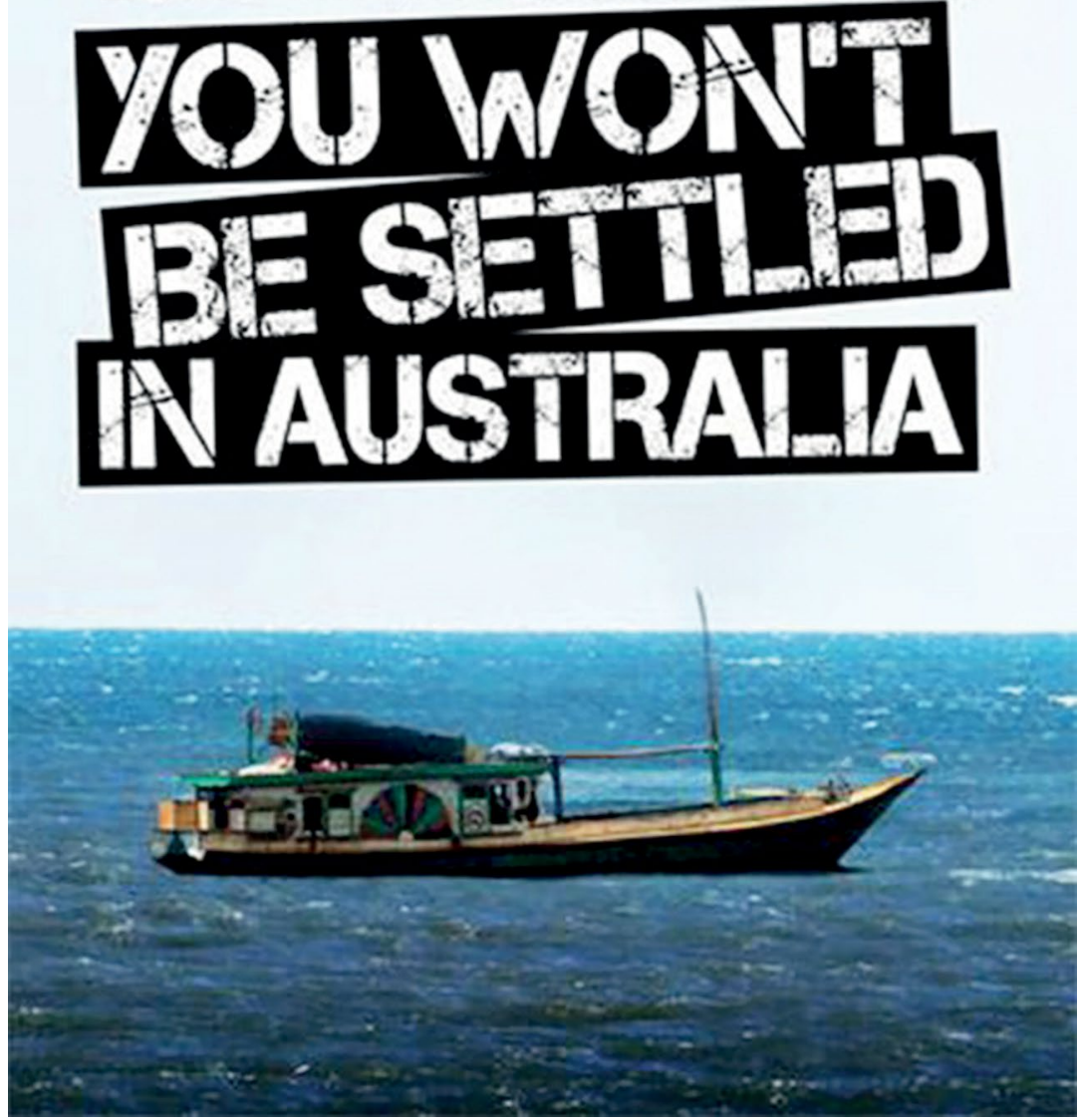

Figure 7.1: 'If you come here by boat'.

Source: Department of Immigration and Citizenship, 2013.

The fate of the Special Humanitarian Program in Australia offers a brief example. As maritime arrivals have increased since 2007, the government has cut back the number of other humanitarian placements we accept by a corresponding amount, notably preventing Australian residents from bringing in family members facing human 
rights abuse abroad. ${ }^{1}$ This linkage had no discernible impact on the number of maritime arrivals. But it has had unintended consequences. In 1999, when a similar linkage policy was introduced, children made up only 13 per cent of asylum seekers. By 2001, faced with the risk of never being able to bring their families out, the proportion of children on boats had risen to one-third. ${ }^{23}$ In October 2001, SIEV-X, an 'illegal entry vehicle', sank en route to Christmas Island, claiming the lives of 353 people. Over 40 per cent were women; over 40 per cent were children. ${ }^{4}$ Since August 2012, the Australian Government has once again denied anyone arriving in Australia on a temporary visa any right to access the split family program. ${ }^{5}$ This particular pain, inutile and destructive, will fall in particular on unaccompanied minors, the most vulnerable of all refugee groups, who face a life indefinitely separated from their parents.

But there is another way of approaching the question of unintended consequences. Let us reject the logic that assumes that all regulation is based on intention. Human attitudes are driven by many underlying beliefs, including our fears, anxieties, and assumptions. We might call these unarticulated drivers of behaviour 'ideology'. Perhaps, as Jacques Lacan suggested, we might even say that the unconscious is the government - a body whose obscure decisions we do not know and whose motivations are kept hidden from us, but which nevertheless produces consequences that influence our behaviour. In the sense of ideology or unconscious motivation, most consequences are unintended. Indeed, it is the fact that they are unintended, and unavailable to scrutiny, that is the very source of their power.

1 Refugee Council of Australia, National and Global Statistics 2013-14, 4. Available at www. refugeecouncil.org.au/r/isub/2013-14-IntakeSub-stat.pdf; Department of Immigration and Citizenship, Fact Sheet 60. Available at: www.border.gov.au.virtual.anu.edu.au/about/corporate/ information/fact-sheets/60refugee; Janet Phillips, 'Asylum Seekers and Refugees: What are the Facts?' Parliamentary Library Background Note. Available at: parlinfo.aph.gov.au/parlInfo/ search/display/display.w3p;query =Id\%3A\%22library\%2Fprspub\%2FHGNW6\%22.

2 Mary Crock and D Ghezelbash, 'Do Loose Lips Bring Ships?: The Role of Policy, Politics and Human Rights in Managing Unauthorised Boat Arrivals' (2010) 19 Griffith Law Review 238, 262. 3 Senate Legal and Constitutional Affairs Legislation Committee, Immigration and Citizenship Portfolio, Supplementary Budget Estimates (Parliament of Australia, 17 October 2011).

4 Marg Hutton, Drownings on the Public Record of People Attempting to Enter Australia Irregularly by Boat Since 1998 (2014). Available at: www.sievx.com/articles/background/ DrowningsTable.pdf; Tony Kevin, Reluctant Rescuers (Union Offset, 2012) 143.

5 Department of Immigration and Citizenship, Humanitarian Program Information Paper 2013-14, 3-4; Chris Bowen, 'Government Implements Expert Panel's Family Reunion recommendation' (Media Release, 22 September 2012). 
So where might we find the ideological assumptions that create a whole unintended worldview? Not, to be sure, in the explicit words of legal regulation; they are far too self-conscious and explicit for that. Not even in the work of the spin-doctors and commentariat, whose words are devised to justify and modify changes in attitude. Ideology - our unconscious government - sits below the level of justification, at the level of perspective or 'common sense'. It just is. We will instead find this framework of meaning not in texts but in images, and in the feelings and responses they evoke. It is these images that shape our response, unbeknownst to us. These images frame how we perceive asylum seekers and govern how we treat them. The whole sorry story of contemporary migration law is but a litany of their unintended consequences. As John Tagg explains it, the image reveals not the logic of an event but the underlying ideology of life's illusions that governs its reception:

What lies 'behind' the paper or 'behind' the image is not reality the referent - but reference: a subtle web of discourse through which realism is enmeshed ... a whole hidden corpus of knowledge, a social knowledge that is called upon through the mechanism of connotation. ${ }^{6}$

In images we will find clues to the attitudes that influence our response to refugees, and whose consequences, powerful precisely because they operate below intention, we see all around us.

The immigration department's most recent advertising campaign shows a rickety boat in a vast empty ocean. Across the picture are emblazoned the words: 'If you come here in a boat without a visa YOU WON'T BE SETTLED IN AUSTRALIA'. ${ }^{7}$ A similar image is on the department's own website, under the heading 'NO WAY' ${ }^{8}$ The image evokes the loneliness and the dangers of undertaking a sea voyage in which over a thousand people have drowned in the past decade. ${ }^{9}$ But it does nothing to tell us about the lives of those on board,

6 John Tagg, The Burden of Representation: Essays on Photographies and Histories (University of Massachusetts Press, 1988) 100.

7 Alana Lentin, 'Refugees: A Call for Open Borders and Free Movement for All', The Guardian, 23 July 2013. Available at: www.theguardian.com/commentisfree/2013/jul/23/open-bordersaustralia-asylum-seekers.

8 Australian Customs and Border Protection, Counter People Smuggling Communication. Available at: www.customs.gov.au/site/offshore-communication-campaign-people-smuggling.asp. ACBPS and DIBP will be merged from 1 July 2015, however, ACBPS was not a part of the department at the time this chapter was written.

$9 \quad$ Marg Hutton, above fn 4. 
and why they have felt compelled to take the dangerous steps they have. Asylum seekers are presented as generic and faceless. While they are worthy of our pity, they are not worthy of our respect.

The same could be said of the coverage of the repatriation of the drowned body of an infant when - yet another - boat sank off Christmas Island in July 2013. Beneath a headline that declared, 'Final journey for policy failure's littlest victim', the iconic image showed the coffin of a 10-week-old boy being loaded into a cargo plane. ${ }^{10}$ The image again combines two key elements in the visual discourse of 'irregular maritime arrivals' in Australia: the victim, who is powerless to avert their fate, the plaything of evil predators (and perhaps of their parents' foolishness); and the Australian rescuer who tries to help but is overwhelmed by sheer numbers. Again, what is lacking is any sense of the actual histories of this child's family or others on board the vessel, not to mention the specific circumstances in which taking to the open ocean was a tragic, but by no means an irrational, decision. ${ }^{11}$ The image congratulates us on our sense of pity - our own capacity for moral empathy - but does not in any way make us feel implicated in its awful chain of events.

In that light, the harshness of Australia's policies becomes a righteous response. Images of detention facilities in places such as Nauru and Manus Island are likewise carefully managed. They keep the viewer at a distance, and show asylum seekers behind barbed wire fences. We are invited to feel a shudder of sublime horror at this fate, but we are never brought close enough to see faces, or engage with individual stories. This specificity might change our relationship to these images, and more to the point we might be brought from a generalised pity of the circumstances of these refugees, to anger at the injustice of our own policies. While barbed wire enclosures, like the open ocean,

10 Paige Taylor, 'Final Journey for Policy Failure's Littlest Victim', The Australian, 29 July 2013. Available at: www.theaustralian.com.au/national-affairs/election-2013/final-journey-for-policyfailures-littlest-victim/story-fn9qr68y-1226687209428.

11 For a comprehensive discussion of the asylum question in Australian law and policy, see Desmond Manderson, 'From Zero Tolerance to Harm Reduction: "The Asylum Problem Problem"' (2013) 32(4) Refugee Survey Quarterly 1; Desmond Manderson, 'Groundhog Day: Why the Asylum Problem is Like the Drug Problem' (2013) 41 Griffith Law Review 84. See also M Crock, B Saul and A Dastyari, Future Seekers II: Refugees and Irregular Migration in Australia (Federation Press, 2006). 
are treated as the law of nature, and asylum seekers as something like wild animals at the mercy of those laws, what we are really invited to experience is our own feelings and our own moral virtue. ${ }^{12}$

To understand exactly how these images operate and with what social and legal effects, it can sometimes help to think about a different image from a different time. By doing this, we can take a dispassionate look at the way images work in framing our responses. ${ }^{13}$ Take a famous picture from the nineteenth century, J M W Turner's The Slave Ship (1840). ${ }^{14}$ The painting is a bravura depiction of sunset and seascape.

Most extraordinary is its subject, given in Turner's original title, Slavers throwing overboard the dead and dying - typhoon coming on. In the foreground, dwarfed by the fury of the sea and obscured by the glare of the sun, are several tiny figures, hands outstretched in futile appeal as they sink beneath the waves, surrounded by the chains of their bondage. On the right, an even more macabre scene plays out, the dead body of a woman already being devoured by fishes as a great shark bears down.

The picture has a specific legal context. In 1781, 132 captive men and women aboard the Zong drowned en route from Africa to the slave markets of the Caribbean. The crew had been ordered by the captain to throw them overboard, so that the ship's owners could claim under an insurance contract that was payable for 'cargo' lost or jettisoned at sea - but not if they died of illness or malnutrition either at sea or after landfall. ${ }^{15}$ Turner's point was not merely of historical interest. Britain had only prohibited slavery in its Caribbean colonies two years previously. In 1840, the question of global abolition was hotly debated and the problem of jettison had not gone away. ${ }^{16}$ Turner's image

12 Sherene Razack, Dark Threats and White Knights: The Somalia Affair, Peacekeeping, and the New Imperialism (University of Toronto Press, 2004).

13 W J T Mitchell (ed.), Art and the Public Sphere (University of Chicago Press, 1992); W J T Mitchell, Picture Theory: Essays on Verbal and Visual Representation (University of Chicago Press, 1994); W J T Mitchell, What do Pictures Want?: The Lives and Loves of Images (Chicago University Press, 2005); David Freedberg, The Power of Images: Studies in the History and Theory of Response (University of Chicago Press, 1989).

14 Joseph Turner, The Slave Ship (Slavers throwing overboard the dead and dying - typhoon coming on), oil on canvas, $90.8 \times 122.6 \mathrm{~cm}$, Museum of Fine Arts, Boston (1840).

15 Gregson v Gilbert (1783) 99 ER 629; John McCoubrey, 'Turner's Slave Ship: Abolition, Ruskin, and Reception' (1998) 14(4) Word and Image 319.

16 See, for example, Spectator, 'Debates and Proceedings in Parliament. Amendment of the Slave Emancipation Act', 17 March 1838, p. 2. 
reminded his viewers of an historical tragedy in order to draw attention to a current issue. It represented the ills of slavery and appealed for the completion of a job half done. ${ }^{17}$

The Slave Ship is probably Turner's most controversial painting. For some critics, it is a stirring indictment of a dark chapter in British history. In these images of death and drowning, we are brought closer to the callous horror of the slave trade. Some have gone further, suggesting that his real subject was not just slavery, but the cold logic of capitalism that reduced human beings to a matter of costs and benefits. The poem that Turner wrote to accompany the painting suggests as much: 'Hope, Hope, fallacious hope/Where is thy market now?' The slaver, the shark, and the capitalist all feast on human flesh. ${ }^{18}$

Other critics vehemently disagree. Many find Turner's painting grotesque and melodramatic. The human figures lack individuality, personality, or history. We do not see their eyes, we do not see their faces. He treats them like animals in death, just as they had been treated in life. The dead and drowning are abject — presented as objects for whom we feel pity, not as subjects to whom we owe respect. Even worse, by turning them into an artwork notable for its gorgeous and subtle colours, is he not exploiting their suffering for his own purposes? ${ }^{19}$ The debate over the meaning of The Slave Ship comes down to whether such images and events can - and should - be represented in art. Does aesthetic portrayal deepen the impact of their suffering, or merely appropriate it for our amusement? It is not an easy question. It is true that there is a maudlin tendency in Turner's depiction of the victims of slavery. They are presented as a group, doomed by nature to suffering, rather than as individuals with perspectives of their own. They are reduced to mere bodies without history or agency. Such an abject portrayal objectifies human beings in a disturbing way: it seems to take from them their dignity. But at the

17 See Paul Gilroy, The Black Atlantic (Cambridge University Press, 1993); Marcus Wood, Blind Memory: Visual Representations of Slavery in England and America, 1780-1865 (Manchester Press, 2000).

18 Jerrold Ziff, 'John Langhorne and Turner's "Fallacies of Hope"”' (1964) 27 Journal of Warburg and Courtauld Institutes 340.

19 See Paul Gilroy, The Black Atlantic (Cambridge University Press, 1993); Abigail Ward, "“Words are all I have left of my eyes": Blinded by the Past in J. M. W. Turner's Slavers Throwing Overboard the Dead and Dying and David Dabydeen's “Turner"' (2007) 42 The Journal of Commonwealth Literature 47. 
same time, Turner emphasises an uncomfortable truth about human existence. To look at the painting is to confront one's own mortality. The loss of dignity and the abrogation of rights comes to us all in the end - in death if not in old age, in old age if not in sickness, in sickness if not in childhood, in childhood if not in birth, in birth if not in sex, in love and in death. This does not remove the question of others' responsibility. On the contrary, it heightens it. In death we are all reduced to the forces of nature, to a lifeless and right-less corpse whose treatment matters just because there is nothing and no one to demand it, except the scruples of those who survive.

Indeed, the disagreement over Turner's painting is a false dichotomy. The Slave Ship depicts both a moral feeling and a moral failing. It represents a system of exploitation - the basis of British prosperity in the eighteenth century - that the Empire was ultimately prepared to recognise and to reject. But it also represents a system of exploitation - the basis of British prosperity in the nineteenth century - that the Empire was not prepared to acknowledge. By representing black people as passive victims, and failing to imagine their capacity for agency, individuality, and history, Turner's painting expresses the moral complacency that actively produced the Empire. The 'white man's burden', as Kipling would call it, presumed that dark-skinned people had to be dragged like unwilling flotsam from the waters of their destiny:

To wait in heavy harness

On fluttered folk and wild -

Your new-caught, sullen peoples,

Half devil and half child. ${ }^{20}$

So the brilliance of Turner's masterpiece lies in his ability to intentionally reveal the story of British slavery, while at the same time unintentionally revealing the mindset of British colonialism. This is what makes many works of art great: they show more than they know. We are always in the presence of not one but two perspectives: the object that is pictured and the gaze that pictures it. In this way, Turner succeeds in illuminating both the insight and the blindness of the nineteenth-century world view.

20 Rudyard Kipling and Thomas James Wise, The White Man's Burden (1899); Rudyard Kipling and R T Jones (eds), The Collected Poems of Rudyard Kipling (Wordsworth Editions Limited, 1994). See also Sherene Razack above fn 12. 
The questions Turner's painting raises, of economic calculation versus human dignity - alive or dead - have not gone away. In June 2013, at least 55 Tamil asylum seekers drowned off Christmas Island. Although an extensive search and rescue operation found no survivors, several dead bodies were located, but never recovered. Border Protection authorities described the decision as 'operational' and claimed that its vessels were needed elsewhere. ${ }^{21}$

With at least three vessels and five aircraft involved in a three-day search, it seems unlikely that Customs had no resources to collect the dead if they had chosen to do so. As the head of the Australian Tamil Congress, Bala Vigneswaran said: 'If the Government, or the decisionmakers, think it is OK to leave the people behind because they are not Australian and they're not worth it - if they want to put it that way — it's not right. ${ }^{22}$

To leave dead bodies in the water, just because it is more convenient to do so, smacks of the kind of instrumental calculation that Turner saw in the story of the slave ship. Yet without an image, without a picture of death as it found those individual lives, the reality is, in some ways, too easy to push into the background of our minds. We are prepared to pity them, of course, in the abstract, as a statistical number of deaths at sea; we are prepared to blame them, even, for the misguided risks they took; what we are not prepared to do is imagine them as people who even in death have families and communities that cherish their bodies and their memories.

At the same time, the other side of Turner's image has its counterpart in contemporary images. The images of asylum seekers with which we are surrounded exploit the same relationships of victimhood, pity, and moral complacency that many critics saw in Turner's canvas. Positioning asylum seekers as victims in the thrall of natural or social forces beyond our control, and ourselves as their well-intentioned but overwhelmed rescuers, blinds us to other questions and perspectives. I mean, for example, the global political structure that treats asylum seeking as a national problem of border control, rather than a regional problem of human security. Or, again, the underlying global economic

21 Judith Ireland, 'Bodies of Drowned Asylum Seekers Left in the Water', Sydney Morning Herald, 9 June 2013. Available at: www.smh.com.au/federal-politics/political-news/bodies-ofdrowned-asylum-seekers-left-in-the-water-20130609-2ny85.html.

22 Ibid. 
structures that assume that capital must be globally free but labour must be tightly controlled. The sincerity of politicians who cry in parliament during debates over the deaths of asylum seekers at sea may do them credit. ${ }^{23}$ But perhaps the lure of pity is that if we see ourselves as rescuers and bystanders, in the end the ones we feel sorriest for are ourselves.

Above all, the images with which I started represent boat arrivals as distant victims and obsess only about how to turn them back. This erases the ways in which we are already implicated in their lives and choices. Refugees are driven out of their own countries by a political instability that we are not wholly innocent of, or by wars in which we have been actively involved. They are also driven to our shores by desires - for wealth, for capitalism, for commodities - that we encourage and need, and by poverty - cheap labour, cheap goods that we are more than keen to exploit. ${ }^{24}$ The brutality of sweatshops and the tyranny of debt in the developing world is part of the global division of labour. Slavery might be thought of as a system that built a high standard of living for some, while choosing to ignore its dependence on the exploitation of others. Colonialism moved this relationship offshore, where it became more prevalent - and less visible. Post-colonialism merely disguises more effectively still the logic of the process behind the fig-leaf of self-government.

Indeed, if we return to the image of The Slave Ship one more time, some odd features are worthy of note. One, that has frequently invited derision, is the way that Turner seems to have painted the heavy iron chains of the slaves as if they were somehow floating on the surface of the water. Another lies in Turner's title, since the picture does not in fact show 'slavers throwing overboard the dead and dying'. The ghostly ship lies far off, engulfed by the typhoon, while the dead and dying are right in front of us. Yet there is an answer to these puzzles. What if Turner was right, and the picture actually shows the very moment when they were in the process of being thrown overboard? Then the image would capture the instant those chains hit the water they would not be floating, but they would not yet have sunk.

23 News.com.au, 'Tears in Parliament Over Asylum-seeker Deaths at Sea', 27 June 2012. Available at: www.news.com.au/national/tears-in-parliament-over-asylum-seeker-deaths-at-sea/ story-e6frfkvr-1226410278096.

24 See Dauvergne, Catherine, Making People Illegal: What Globalization means for Migration and Law (Cambridge University Press, 2008). 
In that case, however, the ship in the distance cannot be responsible. There must be some other ship from which the slavers are throwing the dead and dying. And the solution is simple. We cannot see it because the picture is drawn from its position. The Slave Ship is us. If we think of the painting in this way, if we were the slavers all along, then that would surely change our response to those bodies that lie so close to us in the water. We would owe them something, for they would incite not our pity but our responsibility.

That is a bitter pill to swallow. If, as Turner suggests in his image and his title, there is a 'typhoon coming on', a terrible global reckoning, most of us find it hard to admit, and all of us find it hard to do much about it. Nonetheless, Turner's perspectives - the one he could see and the one he couldn't see - are not mutually exclusive. On the contrary, seeing the one is the condition for seeing the other. If Customs had thought of their own families in that water, I cannot but think that they would have acted, urgently and without calculation. And if we had more and better images and stories of those who set out in the 'fallacious hope', as Turner put it, of reaching this country, we would treat them with more respect. Our government and our agencies might even begin to acknowledge the ways in which we are already part of these stories and these lives.

A critical apprehension of the highly emotive images by which we are bombarded will make us much more aware of the ways in which they work on the subconscious to constitute and govern our emotional responses. ${ }^{25}$ Such a critical apprehension might also encourage the production of other and different images; showing us, for example, the view of the Australian coast from that rickety boat, or documenting the experiences of those behind the razor wire. ${ }^{26}$ Those images already exist, but they do not circulate as often, as reliably, or with the ideological support bestowed on the mainstream images, to which I have alluded in this paper. Nonetheless, even in their relative absence, imagining the framework that has been cut out of the image, so to speak, can still generate a cascade of ironies with powerful effect. ${ }^{27}$ The image of a solider bringing back to Australian soil the coffin

25 Richard Sherwin, Visualizing Law in the Age of the Digital Neo-Baroque (Routledge, 2012); Judith Butler, Frames of War: When is Life Grievable (Verso, 2009); John Tagg above fn 6.

26 Ariella Azoulay, The Civil Contract of Photography (Zone Books, 2008).

27 John Tagg above fn 6. 
of a baby, while his parents and siblings are denied that entry because they are still alive, is just one such irony that can be considered and expounded to show the limitations of our perspective and the consequences of our policies. Visual literacy allows us to reflect on the ways in which images are chosen to enhance particular effects and relationships, and to obfuscate or exclude others. Above all, by allowing us to expand our visual horizons, we may be finally brought to see the responsibility we bear for those who drown at sea - not just in an abstract and sentimental sense, but in an immediate and political sense. Perhaps then our studiously maintained blind spots as to their lives and their deaths would cease.

\section{Bibliography}

\section{Articles, books, and reports}

Azoulay, Ariella, The Civil Contract of Photography (Zone Books, 2008)

Butler, Judith, Frames of War: When is Life Grievable (Verso, 2009)

Crock, M, B Saul and A Dastyari, Future Seekers II: Refugees and Irregular Migration in Australia (Federation Press, 2006)

Crock, Mary and D Ghezelbash, 'Do Loose Lips Bring Ships?: The Role of Policy, Politics and Human Rights in Managing Unauthorised Boat Arrivals', (2010) 19 Griffith Law Review 238

Dauvergne, Catherine, Making People Illegal: What Globalization means for Migration and Law (Cambridge University Press, 2008)

Department of Immigration and Citizenship, Australia's Humanitarian Program 2013-2014

Freedberg, David, The Power of Images: Studies in the History and Theory of Response (University of Chicago Press, 1989)

Gilroy, Paul, The Black Atlantic (Cambridge University Press, 1993)

Kevin, Tony, Reluctant Rescuers (Union Offset, 2012)

Kipling, Rudyard and R T Jones (eds), The Collected Poems of Rudyard Kipling (Wordsworth Editions Limited, 1994) 
Kipling, Rudyard and Thomas James Wise, The White Man's Burden (1899)

Manderson, Desmond, 'Bodies in the Water' (2013) 264 Art Monthly Australia 9

Manderson, Desmond, 'From Zero Tolerance to Harm Reduction: "The Asylum Problem Problem"' (2013) 32(4) Refugee Survey Quarterly 1

Manderson, Desmond, 'Groundhog Day: Why the Asylum Problem is Like the Drug Problem' (2013) 41 Griffith Law Review 84

McCoubrey, John, 'Turner's Slave Ship: Abolition, Ruskin, and Reception' (1998) 14(4) Word and Image 319

Mitchell, W J T (ed.), Art and the Public Sphere (University of Chicago Press, 1992)

Mitchell, W J T, Picture Theory: Essays on Verbal and Visual Representation (University of Chicago Press, 1994)

Mitchell, W J T, What do Pictures Want?: The Lives and Loves of Images (Chicago University Press, 2005)

Razack, Sherene, Dark Threats and White Knights: The Somalia Affair, Peacekeeping, and the New Imperialism (University of Toronto Press, 2004)

Senate Legal and Constitutional Affairs Legislation Committee, Immigration and Citizenship Portfolio, Supplementary Budget Estimates (Parliament of Australia, 17 October 2011)

Sherwin, Richard, Visualizing Law in the Age of the Digital NeoBaroque (Routledge, 2012)

Spectator, 'Debates and Proceedings in Parliament. Amendment of the Slave Emancipation Act', 17 March 1838, p. 2

Tagg, John, The Burden of Representation: Essays on Photographies and Histories (University of Massachusetts Press, 1988)

Ward, Abigail, "'Words are all I have left of my eyes": Blinded by the Past in J. M. W. Turner's Slavers Throwing Overboard the Dead and Dying and David Dabydeen's "Turner"' (2007) 42 The Journal of Commonwealth Literature 47 
UNINTENDED CONSEQUENCES

Wood, Marcus, Blind Memory: Visual Representations of Slavery in England and America, 1780-1865 (Manchester Press, 2000)

Ziff, Jerrold, 'John Langhorne and Turner's "Fallacies of Hope"' (1964) 27 Journal of Warburg and Courtauld Institutes 340

\section{Cases}

Gregson v Gilbert (1783) 99 ER 629

\section{Other}

Australian Customs and Border Protection, Counter People Smuggling Communication. Available at: www.customs.gov.au/site/offshorecommunication-campaign-people-smuggling.asp

Bowen, Chris, 'Government Implements Expert Panel's Family Reunion recommendation' (Media Release, 22 September 2012)

Department of Immigration and Citizenship, Fact Sheet 60 (2013). Available at: www.border.gov.au.virtual.anu.edu.au/about/ corporate/information/fact-sheets/60refugee

Hutton, Marg, Drownings on the Public Record of People Attempting to Enter Australia Irregularly by Boat Since 1998 (2014). Available at: www.sievx.com/articles/background/DrowningsTable.pdf

Ireland, Judith, 'Bodies of Drowned Asylum Seekers Left in the Water', Sydney Morning Herald, 9 June 2013. Available at: www. smh.com.au/federal-politics/political-news/bodies-of-drownedasylum-seekers-left-in-the-water-20130609-2ny85.html

Lentin, Alana, 'Refugees: A Call for Open Borders and Free Movement for All', The Guardian, 23 July 2013. Available at: www.theguardian. com/commentisfree/2013/jul/23/open-borders-australia-asylumseekers

News.com.au, 'Tears in Parliament Over Asylum-seeker Deaths at Sea', 27 June 2012. Available at: www.news.com.au/national/ tears-in-parliament-over-asylum-seeker-deaths-at-sea/storye6frfkvr-1226410278096 
Phillips, Janet, 'Asylum Seekers and Refugees: What are the Facts?' Parliamentary Library Background Note. Available at: parlinfo.aph. gov.au/parlInfo/search/display/display.w3p;query=Id \%3A \%22li brary \%2Fprspub\%2FHGNW6\%22

Refugee Council of Australia, National and Global Statistics 201314. Available at: www.refugeecouncil.org.au/r/isub/2013-14IntakeSub-stat.pdf

Taylor, Paige, 'Final Journey for Policy Failure's Littlest Victim', The Australian, 29 July 2013. Available at: www.theaustralian. com.au/national-affairs/election-2013/final-journey-for-policyfailures-littlest-victim/story-fn9qr68y-1226687209428

Turner, Joseph, The Slave Ship (Slavers throwing overboard the dead and dying - typhoon coming on), oil on canvas, $90.8 \times 122.6 \mathrm{~cm}$, Museum of Fine Arts, Boston (1840) 
This text is taken from Unintended Consequences: The impact of migration law and policy, edited by Marianne Dickie, Dorota Gozdecka and Sudrishti Reich, published 2016 by ANU Press, The Australian National University, Canberra, Australia.

The papers published in this book arose from an inaugural conference on migration law and policy at ANU College of Law, held in October 2013. They are reprinted here with minor amendments. 